Article

\title{
[2 + 2] Photodimerization of Naphthylvinylpyridines through Cation- $\pi$ Interactions in Acidic Solution
}

\author{
Shinji Yamada * and Yuka Nojiri \\ Department of Chemistry, Ochanomizu University, 2-1-1 Otsuka, Bunkyo-ku, Tokyo 112-8610, Japan; \\ yuka.nojiri@konicaminolta.com \\ * Correspondence: yamada.shinji@ocha.ac.jp; Tel.: +81-3-5978-5349 \\ Academic Editor: Shunichi Fukuzumi \\ Received: 21 February 2017; Accepted: 15 March 2017; Published: 20 March 2017
}

\begin{abstract}
Irradiation of (E)-4-(2-(2-naphthyl)vinyl)pyridine (1a) and (E)-4-(2-(1-naphthyl)vinyl)pyridine (1b) with a $250 \mathrm{~W}$ high-pressure mercury lamp in acidic solution afforded synHT dimers in high stereoselectivities. Similar results were obtained by visible light irradiation. On the other hand, when the reactions were carried out under neutral conditions, the stereoselectivities were very low, and the yields were decreased by visible light irradiation. Comparison of the UV-vis spectra between the acidic and the neutral conditions elucidated that the red shift was observed in acidic solutions. These results show that $\mathrm{HCl}$ plays essential roles not only in the preorientation of substrates through cation- $\pi$ interactions, but also in the changes in the absorption properties of substrates that enable visible light reactions.
\end{abstract}

Keywords: cation- $\pi$ interaction; $[2+2]$ photodimerization; cyclobutane derivative; naphthylvinylpyridine; stereoselective reaction

\section{Introduction}

Controlling the association mode of substrate alkenes during [2 +2] photodimerization is a key subject in organic photochemistry [1-4], as it is essential for the regio- and stereoselective formation of cyclobutane dimers. Various approaches for the alignment of molecules have been developed using a variety of organized media [5], organic crystals [6-10], metal-organic frameworks [11,12], metal complexes $[13,14]$, and supramolecular systems $[15,16]$. Previously, we reported that a cation- $\pi$ interaction [17] between a pyridinium salt and a benzene ring plays an essential role on the product distribution in the [2+2] photodimerization of styrylpyridines [18-20]. This preorientation process is responsible for various stereoselective photodimerization reactions not only in solution, but also in crystals $[21,22]$.

It has been reported that the size of the $\pi$-system is significantly correlated with the strength of the cation- $\pi$ interactions; for example, the interaction energy of a sodium cation with naphthalene is $2-3.5 \mathrm{kcal} / \mathrm{mol}$ larger than that with benzene [23,24]. This prompted us to investigate the [2 +2] photodimerization of naphthylvinylpyridines having more extended $\pi$-systems than those of styrylpyridines. In this paper, we report that the photodimerization of naphthylvinylpyridines $1 \mathbf{a}$ and $\mathbf{1 b}$ (Figure 1) in acidic solution provides synHT dimers with very high regio- and stereoselectivities through cation- $\pi$ interaction, even under irradiation with visible light. 
<smiles>C(=C/c1ccc2ccccc2c1)\c1ccncc1</smiles>

$1 \mathrm{a}$<smiles>C(=C/c1cccc2ccccc12)\c1ccncc1</smiles>

$1 b$

Figure 1. Substrates for photodimerization.

\section{Results and Discussion}

(E)-4-(2-(2-Naphthyl)vinyl)pyridine (1a) [25] and (E)-4-(2-(1-naphthyl)vinyl)pyridine (1b) [25] were employed as substrates for the photochemical reactions, the $\pi$-conjugate systems of which differed from each other (Figure 1). Irradiation of 1a in a 1.0 M THF solution with a $450 \mathrm{~W}$ high-pressure mercury lamp for $8 \mathrm{~h}$ under neutral conditions afforded all four possible dimers $\mathbf{2 a} \mathbf{-} \mathbf{5 a}$. SynHT dimer $\mathbf{3 a}$ was the major product, but the selectivity was quite low-as shown in Table 1 (entry 1 ). The conversion and the product ratios were determined based on ${ }^{1} \mathrm{H}-\mathrm{NMR}$ spectra. Though the reaction was carried out in a $0.067 \mathrm{M} \mathrm{MeOH}$ solution due to the much lower solubility of 1a than that in THF, a similar result was observed (entry 2). Photolysis in the presence of 1 equiv. of conc. hydrochloric acid resulted in remarkable changes in the product distribution (entry 3); the synHT adduct 2a increased to become the major product along with a small amount of $3 \mathbf{a}$ and $4 \mathbf{a}$. As the amount of $\mathrm{HCl}$ loading increased to 3 equiv., the yield of the synHT dimer 2a increased to $93 \%$ (entry 4).

Table 1. UV irradiation of $\mathbf{1 a}$ and $\mathbf{1 b} .^{\mathrm{a}}$

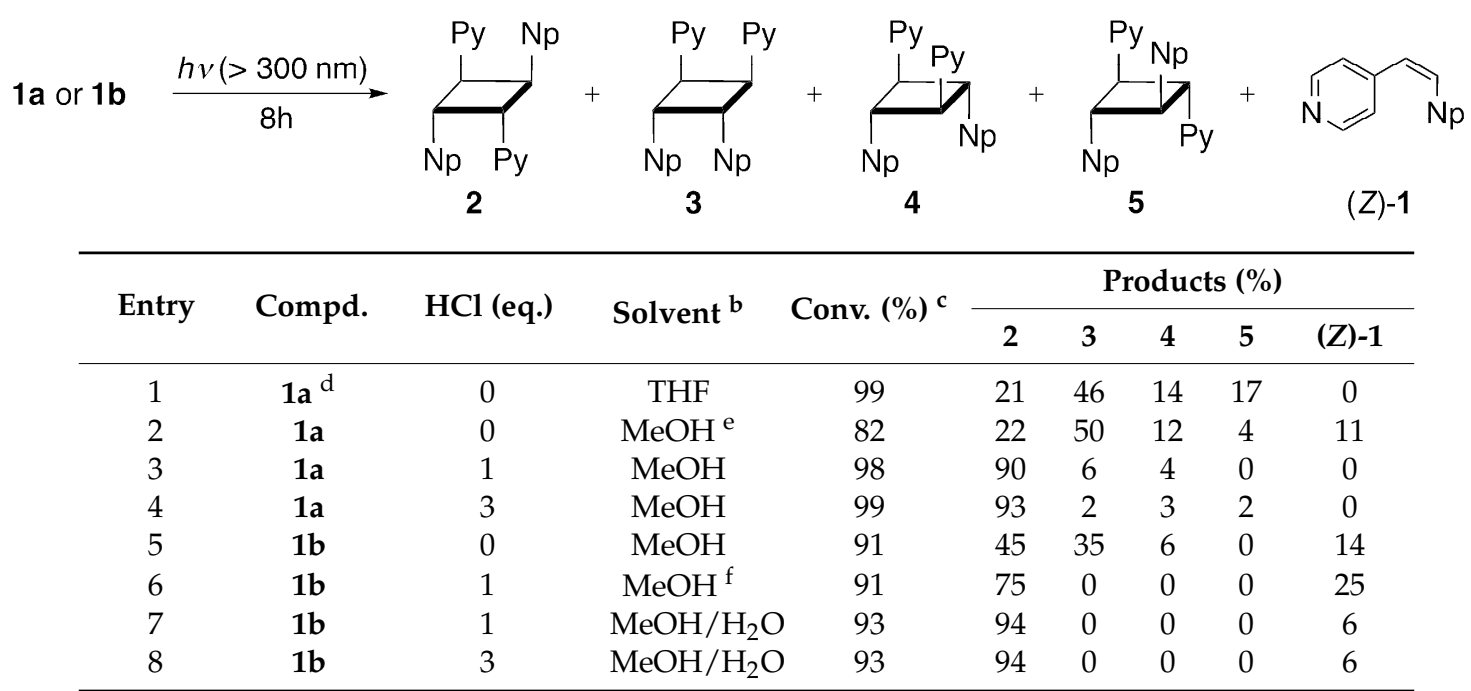

a External irradiation was carried out through Pyrex filter in cooling water. ${ }^{\mathrm{b}}$ A $1.0 \mathrm{M}$ solution was employed unless otherwise noted. ${ }^{\mathrm{c}}$ Determined by ${ }^{1} \mathrm{H}-\mathrm{NMR}$. ${ }^{\mathrm{d}}$ Naphtha $[2,1-h]$ isoquinoline was obtained in $2 \%$ yield. e A $0.067 \mathrm{M}$ solution was used. ${ }^{\mathrm{f}} \mathrm{A} 0.67 \mathrm{M}$ solution was used.

Figure 2a,b show the ${ }^{1} \mathrm{H}-\mathrm{NMR}$ spectra of $1 \mathrm{a}$ after irradiation in the absence and presence of 3 equiv. of $\mathrm{HCl}$, respectively. A comparison clearly demonstrates the significant effect of the acid on the product distribution. Figure 2a shows multi-peaks around $\delta 3.7$ to 4.8 for the methine protons of the four cyclobutane dimers. On the other hand, in the presence of 3 equiv. of $\mathrm{HCl}$, the four methine protons appear at $\delta 4.59$ and 4.62 , indicating exclusive formation of $\mathbf{2 a}$ (Figure $2 \mathrm{~b}$ ).

Irradiation of $\mathbf{1 b}$ in the absence of the acid gave a mixture of $\mathbf{2} \mathbf{b}-\mathbf{4} \mathbf{b}$ and (Z)-isomer (entry 5 ). In the presence of 1 equiv. of $\mathrm{HCl}$, the solubility of $\mathbf{1 b}$ decreased; therefore, the reaction was carried out in a $0.67 \mathrm{M} \mathrm{MeOH}$ solution. The acid demonstrated a significant effect similar to that in the case of $\mathbf{1 a}$; synHT dimer $\mathbf{2} \mathbf{b}$ was obtained in $75 \%$ yield with no other dimers along with $25 \%$ of $(Z)$-isomer (entry 6). A survey of the solvents found that a 9:1 mixture of $\mathrm{MeOH}$ and $\mathrm{H}_{2} \mathrm{O}$ had a good solubility for $\mathbf{1 b} \cdot \mathrm{HCl}$. Using this solvent system, irradiation of a $1.0 \mathrm{M}$ solution of $\mathbf{1 b}$ in the presence of acid 
significantly improved the selectivity to $94 \%$, suggesting the importance of concentration in obtaining good selectivities in these reactions (entries 7 and 8 ).

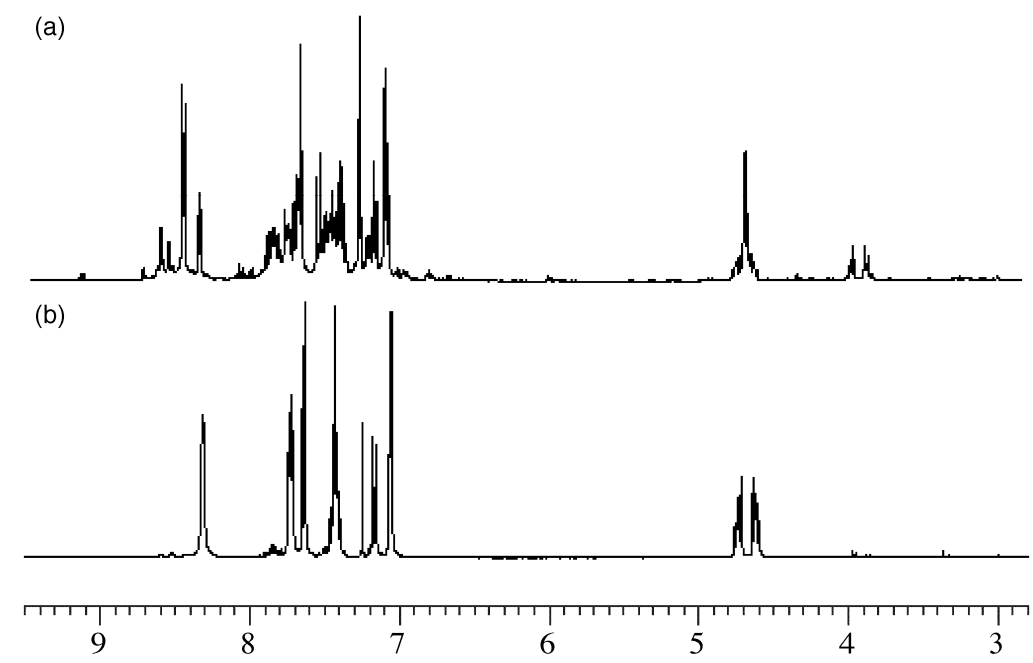

Figure 2. ${ }^{1} \mathrm{H}-\mathrm{NMR}$ spectra in $\mathrm{CDCl}_{3}$ for (a) $\mathbf{1 a}$ after irradiation for $24 \mathrm{~h}$; and (b) $\mathbf{1 a}$ after irradiation in the presence of 3 eq. of $\mathrm{HCl}$ and successive neutralization.

Another remarkable feature observed under the acidic conditions was that visible light could also induce photodimerization. When the irradiation of $\mathbf{1 a}$ was carried out with a $250 \mathrm{~W}$ high-pressure mercury lamp through a UV-cut filter for $3 \mathrm{~h}$, only (Z)-isomer was produced in $7 \%$ yield (Table 2, entry 1). On the contrary, in the presence of $\mathrm{HCl}$, the reaction proceeded to provide synHT dimer $2 \mathbf{a}$ in a similar selectivity to that obtained by UV-light irradiation (entry 2). Irradiation of $\mathbf{1 b}$ in the absence of the acid gave dimers $\mathbf{2} \mathbf{b}$ and $\mathbf{3 b}$ in low yields, whereas in the presence of the acid, $\mathbf{2} \mathbf{b}$ was produced in a significantly high yield (entries 3 and 4 ).

Table 2. Visible-light irradiation of $\mathbf{1 a}$ and $\mathbf{1 b}$. $^{\mathrm{a}}$

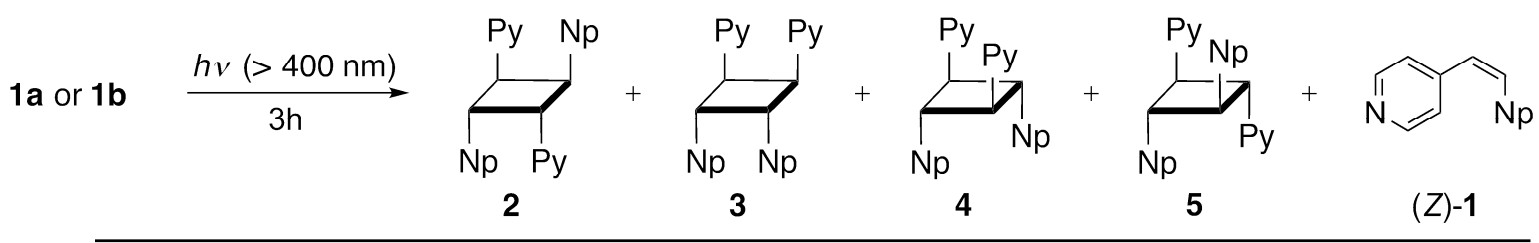

\begin{tabular}{|c|c|c|c|c|c|c|c|c|c|}
\hline \multirow{2}{*}{ Entry } & \multirow{2}{*}{ Compd. } & \multirow{2}{*}{$\mathrm{HCl}$ (eq.) } & \multirow{2}{*}{ Solvent } & \multirow{2}{*}{ Conv. (\%) } & \multicolumn{5}{|c|}{ Products $(\%) b, c$} \\
\hline & & & & & 2 & 3 & 4 & 5 & (Z)-1 \\
\hline 1 & $1 \mathrm{a}$ & 0 & THF & 7 & 0 & 0 & 0 & 0 & 100 \\
\hline 2 & $1 \mathrm{a}$ & 1 & $\mathrm{MeOH}$ & 99 & 93 & 3 & 2 & 2 & 0 \\
\hline 3 & $1 b$ & 0 & $\mathrm{MeOH}$ & 48 & 46 & 39 & 0 & 0 & 15 \\
\hline 4 & $1 b$ & 1 & $\mathrm{MeOH} / \mathrm{H}_{2} \mathrm{O}$ & 88 & 90 & 0 & 0 & 0 & 10 \\
\hline
\end{tabular}

a Spot irradiation was carried out through quartz fibers with a UV-cut filter. ${ }^{\mathrm{b}}$ A $1.0 \mathrm{M}$ solution was employed unless otherwise noted. ${ }^{\mathrm{c}}$ Determined by ${ }^{1} \mathrm{H}-\mathrm{NMR}$.

The remarkable differences in the photoreactivities whether in the presence or absence of $\mathrm{HCl}$ can be explained by differences in their absorption properties. UV-vis spectra for $\mathbf{1 a}, \mathbf{1} \mathbf{b}, \mathbf{1 a} \cdot \mathrm{HCl}$, and $\mathbf{1 b} \cdot \mathbf{H C l}$ are shown in Figure 3. The longest absorption bands of $\mathbf{1 a}$ and $\mathbf{1} \mathbf{b}$ in $\mathrm{MeOH}$ appeared at 319.0 and $331.0 \mathrm{~nm}$, respectively. On the other hand, in the presence of $\mathrm{HCl}$ these bands were shifted to longer wavelengths and observed at 331.0 and ca. $360 \mathrm{~nm}$, respectively, the shoulders of which exceeded $400 \mathrm{~nm}$. These changes in the absorption properties induced by the acid are thought to be responsible for the visible light photodimerization in acidic media. 
(a)

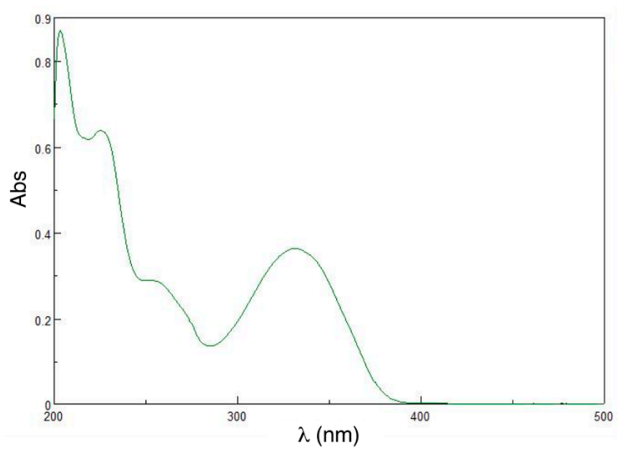

(c)

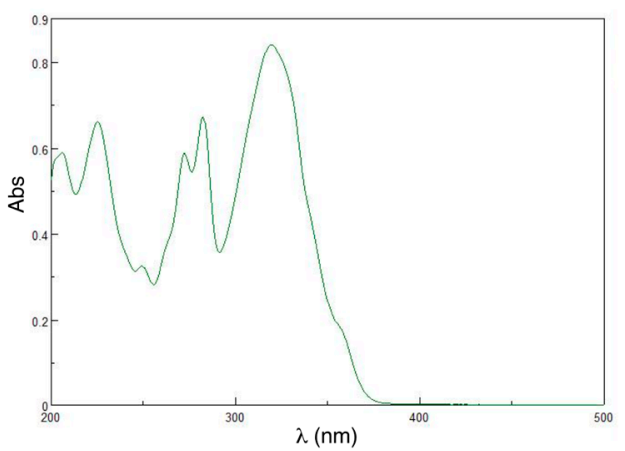

(b)

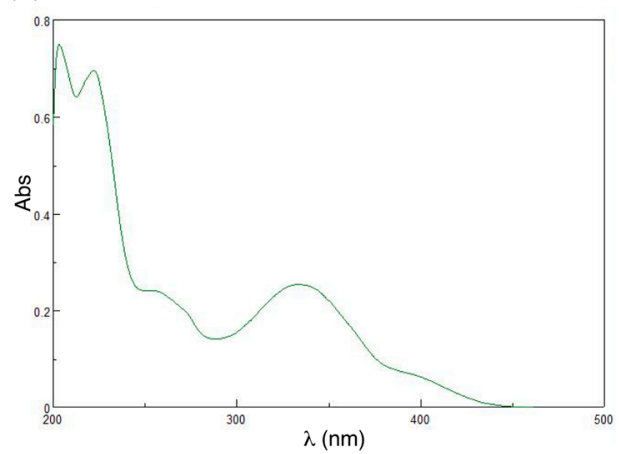

(d)

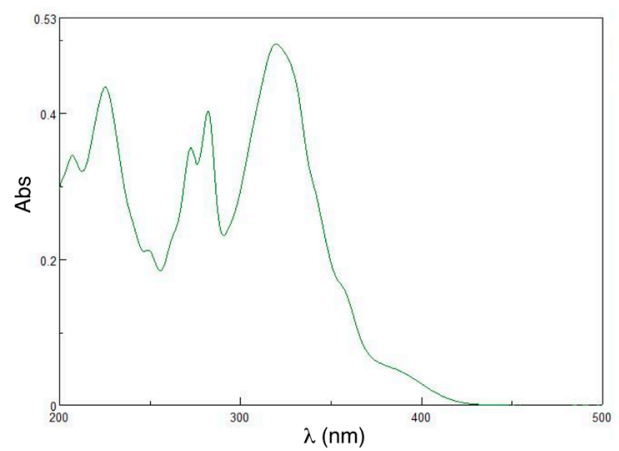

Figure 3. UV-vis spectra in EtOH for (a) $\mathbf{1 a}\left(2.09 \times 10^{-5} \mathrm{~mol} / \mathrm{L}\right)$; (b) $\mathbf{1 a} \cdot \mathrm{HCl}\left(1.80 \times 10^{-5} \mathrm{~mol} / \mathrm{L}\right)$; (c) $\mathbf{1 b}$ $\left(2.34 \times 10^{-5} \mathrm{~mol} / \mathrm{L}\right)$; and $(\mathbf{d}) \mathbf{1 b} \cdot \mathrm{HCl}\left(1.82 \times 10^{-5} \mathrm{~mol} / \mathrm{L}\right)$.

The structures of the product dimers were determined from X-ray crystallographic analyses and the ${ }^{1} \mathrm{H}-\mathrm{NMR}$ and MS spectra. The X-ray analyses were carried out for $\mathbf{2 a}, \mathbf{2} \mathbf{b} \cdot 2 \mathrm{HCl}, \mathbf{3} \mathbf{b}$, and $\mathbf{4 a}$, as single crystals suitable for X-ray analyses were obtained. Figure 4 clearly shows that $\mathbf{2 a}$ and $\mathbf{2 b}$ are $s y n \mathrm{HT}$ dimers, and $\mathbf{3 b}$ and $\mathbf{4 a}$ are $s y n \mathrm{HH}$ and antiHT dimers, respectively. Based on MS and ${ }^{1} \mathrm{H}-\mathrm{NMR}$ analyses, $3 \mathbf{a}$ and $5 \mathbf{a}$ were assigned as syn $\mathrm{HH}$ and ant $i \mathrm{HH}$ dimers, respectively. In their MS spectra, the fragment peaks of $m / z 231$ and 280 were observed. The peak of $m / z 231$ corresponds to a naphthylethylpyridine moiety, and the peak of $m / z 280$ corresponds to a binaphthylethane moiety, indicating their head-to-head structures (Figures S8, S9, S12, and S13). The methine protons at $\delta 4.67$ and 4.69 for $\mathbf{3 a}$ and $\delta 3.88$ and 3.97 for $\mathbf{5 a}$ are very close to those of related synHH and antiHH dimers, respectively [18]. The assignment of $\mathbf{4} \mathbf{b}$ was also performed by MS spectra; the observations of a base peak of $m / z 231$ with no peak of $m / z 280$ are characteristic of the head-to-tail structures (Figures S10 and S11). In addition, since $\mathbf{2} \mathbf{b}$ was assigned as a synHT dimer by X-ray analysis, $\mathbf{4 b}$ should be an antiHT dimer.

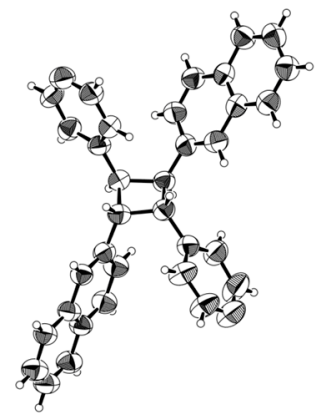

$2 \mathbf{a}$

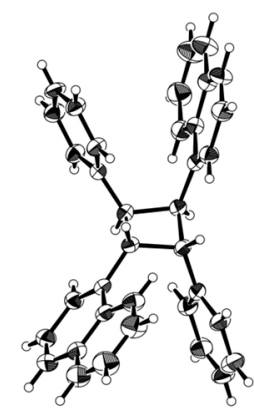

$2 \mathbf{b}$

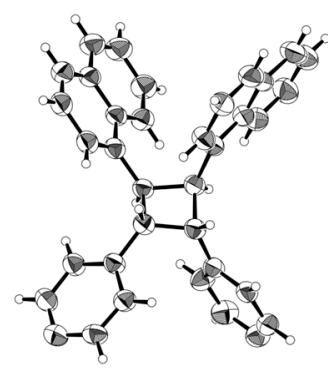

$3 b$

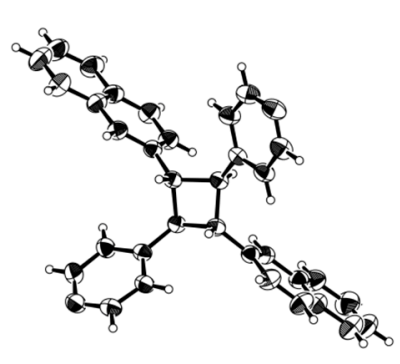

$4 a$

Figure 4. X-ray structures of $\mathbf{2 a}, \mathbf{2 b} \cdot 2 \mathrm{HCl}, \mathbf{3 b}$, and $\mathbf{4 a}$. 
To obtain mechanistic insights into the dimerization process, the dependence of product distribution on the irradiation time was investigated. Figure 5 shows a plots of the yields of $s y n$ HT dimer $2 \mathbf{a}$ vs. irradiation time. The yield of $2 \mathbf{a}$ increased with increased irradiation time, with the curve following second-order kinetics. This suggests that the dimerization process does not involve any other processes, such as a reverse reaction or isomerization reaction. The second-order kinetics was confirmed by plots of $\mathrm{t}$ vs. 1/[1a], in which a linear correlation was observed (Figure S14).

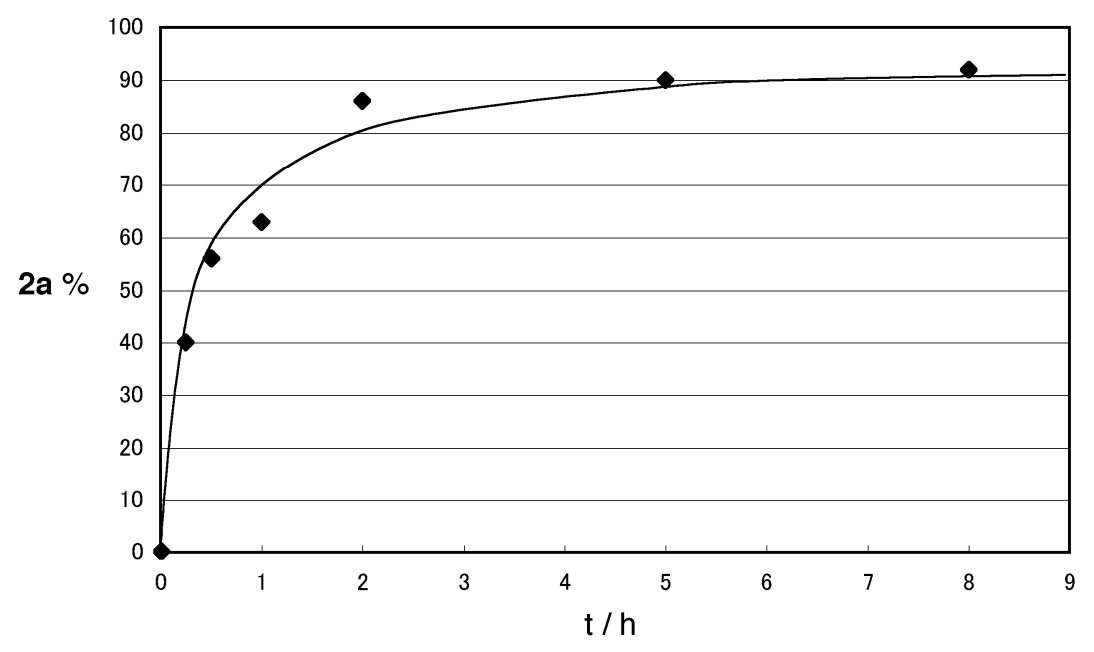

Figure 5. Plots of the yield of 2a vs. irradiation time.

The preference for the formation of the synHT dimer in the presence of $\mathrm{HCl}$ agrees with that in the photodimerization of styrylpyridine [18]. This synHT preference indicates that the intermediate naphthylvinylpyridinium salts form preorganized head-to-tail molecular dimers through intermolecular cation- $\pi$ interactions, as shown in Scheme 1 . The fact that the selectivities observed in the photodimerization of $\mathbf{1 a}$ and $\mathbf{1} \mathbf{b}$ are much higher than that in the case of styrylpyridine (71\% selectivity) [18] suggests a significant effect of the naphthyl group on the intermolecular cation- $\pi$ interactions, regardless of the differences in the $\pi$-conjugate systems.

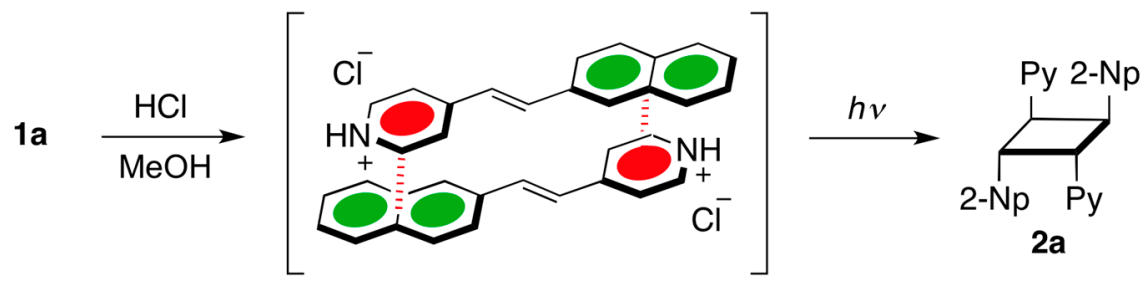

Scheme 1. Formation of a synHT dimer 2a through cation- $\pi$ interactions.

It has been reported that the larger aromatic $\pi$-conjugate systems are more effective for cation- $\pi$ interactions. For example, the threshold collision-induced dissociation technique clarified that extended $\pi$-network leads to an increase in the strength of the cation- $\pi$ interaction due to increased polarizability of the ligand [23]. The B3LYP calculations for the binding energy of $\mathrm{Na}^{+} \ldots$ naphthalene predicted that the energy is larger than that of $\mathrm{Na}^{+} \ldots$ benzene [24]. These experimental and theoretical studies agree with the higher selectivities observed in the photodimerization of $\mathbf{1 a}$ and $\mathbf{1 b}$ than that of styrylpyridine. 


\section{Materials and Methods}

\subsection{General Methods}

Melting points were determined with a Yanaco model MP microscope (Yanaco, Tokyo, Japan). Column chromatography was carried out using silica gel $60 \mathrm{~N}$ (Kanto Chemical, Tokyo, Japan). Thin layer chromatography (TLC) was carried out on a Merck silica gel 60 PF $_{254}$ (Merck, Tokyo, Japan). IR spectra were obtained on FT/IR-410 spectrometer (JASCO, Tokyo, Japan) as neat films between $\mathrm{NaCl}$ plates, or KBr pellets. NMR spectra were recorded on JEOL EX-400 spectrometer (JEOL, Tokyo, Japan). ${ }^{1} \mathrm{H}-\mathrm{NMR}$ spectra were obtained at $400 \mathrm{MHz}$ as dilute solution in $\mathrm{CDCl}_{3}$, and the chemical shifts were reported relative to internal TMS. Low-resolution mass spectra were recorded at ionizing voltage of $70 \mathrm{eV}$ by electron impact. High-resolution mass spectra were recorded on Exactive Orbitrap LC-MS (Thermo-Fischer, Yokohama, Japan). UV/vis spectra were recorded on JASCO V-650DS spectrometer (JASCO, Tokyo, Japan) in $\mathrm{MeOH}$. UV irradiation was performed using a $450 \mathrm{~W}$ high-pressure mercury lamp (USHIO UM453, Tokyo, Japan). Visible-light irradiation was performed using a $250 \mathrm{~W}$ high-pressure mercury lamp (ASAHI SPECTRA REX-250, Tokyo, Japan) through quartz fibers with a UV-cut filter.

\subsection{Representative Procedure for Irradiation of Naphthylvinylpyridines under Acidic Conditions}

A solution of naphthylvinylpyridine $(0.1 \mathrm{mmol})$ in $100 \mu \mathrm{L}$ of $\mathrm{MeOH}$ containing conc. $\mathrm{HCl}$ was irradiated for $8 \mathrm{~h}$ through a Pyrex filter with a $450 \mathrm{~W}$ high-pressure mercury lamp. The solution was neutralized with sat. $\mathrm{NaHCO}_{3}$, and the solvent was evaporated to give an oil. This oil was extracted with $\mathrm{CH}_{2} \mathrm{Cl}_{2}$ three times, and the combined organic layer was dried over anhydrous $\mathrm{MgSO}_{4}$. Evaporation of the solvent gave a crude product, which was subjected to column chromatography on silica gel with a 7:2:1 mixture of ethyl acetate, hexane, and methanol as an eluent. The product ratio was determined by the ${ }^{1} \mathrm{H}-\mathrm{NMR}$ spectrum of the crude product. Visible-light irradiation of the above-mentioned solution was carried out with a $250 \mathrm{~W}$ high-pressure mercury lamp for $3 \mathrm{~h}$ through a UV-cut filter. The work-up followed the same procedure as that described above.

Compound 2a: Pale-yellow crystals; m.p. $196-197{ }^{\circ} \mathrm{C} ;{ }^{1} \mathrm{H}-\mathrm{NMR}\left(400 \mathrm{MHz}, \mathrm{CDCl}_{3}\right) \delta 8.32(\mathrm{~d}, \mathrm{~J}=5.6 \mathrm{~Hz}$, $4 \mathrm{H}), 7.72-7.75(\mathrm{~m}, 4 \mathrm{H}), 7.63-7.65(\mathrm{~m}, 4 \mathrm{H}), 7.42-7.45(\mathrm{~m}, 4 \mathrm{H}), 7.17(\mathrm{dd}, J=8.6,2.0 \mathrm{~Hz}, 2 \mathrm{H}), 7.06(\mathrm{~d}$, $J=6.0 \mathrm{~Hz}, 4 \mathrm{H}), 4.72-4.77(\mathrm{~m}, 2 \mathrm{H}), 4.60-4.64(\mathrm{~m}, 2 \mathrm{H})$; IR (KBr) 3018, 1597, 1552, 1509, 1414, 994, 861, 813, $763 \mathrm{~cm}^{-1}$; MS m/z $462\left(\mathrm{M}^{+}, 0.6 \%\right), 232$ (20), 231 (100), 230 (64), 203 (8), 202 (13). HRMS calcd. for $\mathrm{C}_{34} \mathrm{H}_{27} \mathrm{~N}_{2} 463.21742,(\mathrm{M}+\mathrm{H})^{+}$, found 463.21501.

Compound 3a: Pale-yellow crystals; m.p. $113-114{ }^{\circ} \mathrm{C} ;{ }^{1} \mathrm{H}-\mathrm{NMR}\left(400 \mathrm{MHz}, \mathrm{CDCl}_{3}\right) \delta 8.43(\mathrm{~d}, J=4.4 \mathrm{~Hz}$, $4 \mathrm{H}), 7.65-7.69(\mathrm{~m}, 6 \mathrm{H}), 7.53(\mathrm{~d}, J=8.0 \mathrm{~Hz}, 2 \mathrm{H}), 7.34-7.42(\mathrm{~m}, 4 \mathrm{H}), 7.15(\mathrm{dd}, J=8.6,2.0 \mathrm{~Hz}, 2 \mathrm{H}), 7.09(\mathrm{~d}$, $J=6.0 \mathrm{~Hz}, 4 \mathrm{H}), 4.66-4.70(\mathrm{~m}, 4 \mathrm{H})$; IR (KBr) 3053, 2972, 1599, 1508, 1422, 1115, 995, 820, $746 \mathrm{~cm}^{-1}$; MS m/z $462\left(\mathrm{M}^{+}, 0.6 \%\right), 280$ (26), 279 (18), 232 (39), 231 (100), 230 (96), 202 (13). HRMS calcd. for $\mathrm{C}_{34} \mathrm{H}_{27} \mathrm{~N}_{2}$ $463.21742(\mathrm{M}+\mathrm{H})^{+}$, found 463.21715 .

Compound 4a: Pale-yellow crystals; m.p. $225-226{ }^{\circ} \mathrm{C} ;{ }^{1} \mathrm{H}-\mathrm{NMR}\left(400 \mathrm{MHz}, \mathrm{CDCl}_{3}\right) \delta 8.53(\mathrm{~d}, J=4.8 \mathrm{~Hz}$, $4 \mathrm{H}), 7.80-7.89(\mathrm{~m}, 8 \mathrm{H}), 7.46-7.52(\mathrm{~m}, 6 \mathrm{H}), 7.21(\mathrm{~d}, J=6.0 \mathrm{~Hz}, 4 \mathrm{H}), 3.96-4.01(\mathrm{~m}, 2 \mathrm{H}), 3.84-3.89(\mathrm{~m}, 2 \mathrm{H})$; IR (KBr) 3053, 2927, 1597, 1415, 1068, 817, $751 \mathrm{~cm}^{-1} ; \mathrm{MS} \mathrm{m} / z 462\left(\mathrm{M}^{+}, 1.2 \%\right), 232$ (26), 231 (100), 230 (89), 202 (18). HRMS calcd. for $\mathrm{C}_{34} \mathrm{H}_{27} \mathrm{~N}_{2} 463.21742(\mathrm{M}+\mathrm{H})^{+}$, found 463.21560.

Compound 5a: A colorless oil; ${ }^{1} \mathrm{H}-\mathrm{NMR}\left(400 \mathrm{MHz}, \mathrm{CDCl}_{3}\right) \delta 8.57(\mathrm{~d}, J=6.0 \mathrm{~Hz}, 4 \mathrm{H}), 7.78-7.83(\mathrm{~m}$, $6 \mathrm{H}), 7.75(\mathrm{~s}, 2 \mathrm{H}), 7.45-7.48(\mathrm{~m}, 4 \mathrm{H}), 7.40(\mathrm{dd}, J=8.6,2.0 \mathrm{~Hz}, 2 \mathrm{H}), 7.25-7.26(\mathrm{~m}, 4 \mathrm{H}), 3.96-3.98(\mathrm{~m}, 2 \mathrm{H})$, 3.86-3.89 (m, 2H); IR (KBr) 3054, 2927, 1597, 1415, 1068, 817, $751 \mathrm{~cm}^{-1}$; MS m/z $462\left(\mathrm{M}^{+}, 3.7 \%\right), 370$ (13), 281 (11), 280 (44), 279 (27), 278 (15), 232 (37), 231 (100), 230 (89), 229 (13), 202 (15). HRMS calcd. for $\mathrm{C}_{34} \mathrm{H}_{27} \mathrm{~N}_{2} 463.21742(\mathrm{M}+\mathrm{H})^{+}$, found 463.21693 .

Compound 2b: Pale-yellow crystals; $263-265{ }^{\circ} \mathrm{C} ;{ }^{1} \mathrm{H}-\mathrm{NMR}\left(400 \mathrm{MHz}, \mathrm{CDCl}_{3}\right) \delta 8.20(\mathrm{~d}, J=6.0 \mathrm{~Hz}, 4 \mathrm{H})$, $7.97(\mathrm{~d}, J=8.4 \mathrm{~Hz}, 2 \mathrm{H}), 7.79(\mathrm{~d}, J=8.0 \mathrm{~Hz}, 2 \mathrm{H}), 7.68(\mathrm{~d}, J=8.4 \mathrm{~Hz}, 2 \mathrm{H}), 7.43-7.50(\mathrm{~m}, 6 \mathrm{H}), 7.36-7.40(\mathrm{~m}$, 
2H), $7.02(\mathrm{dd}, J=4.4,1.2 \mathrm{~Hz}, 4 \mathrm{H}), 5.26(\mathrm{dd}, J=9.6,7.6 \mathrm{~Hz}, 2 \mathrm{H}), 4.86(\mathrm{dd}, J=9.6,7.6 \mathrm{~Hz}, 2 \mathrm{H}) ; \mathrm{IR}(\mathrm{KBr})$ 3035, 1597, 1507, 1478, 1416, 996, 801, 773, $681 \mathrm{~cm}^{-1}$; MS m/z $462\left(\mathrm{M}^{+}, 0.2 \%\right), 232$ (30), 231 (100), 230 (81), 203 (7), 202 (12), 153 (21), 152 (13). HRMS calcd. for $\mathrm{C}_{34} \mathrm{H}_{27} \mathrm{~N}_{2} 463.21742(\mathrm{M}+\mathrm{H})^{+}$, found 463.21440.

Compound 3b: White crystals; $206-208{ }^{\circ} \mathrm{C} ;{ }^{1} \mathrm{H}-\mathrm{NMR}\left(400 \mathrm{MHz}, \mathrm{CDCl}_{3}\right) \delta 8.45(\mathrm{~d}, J=6.0 \mathrm{~Hz}, 4 \mathrm{H}), 7.89$ $(\mathrm{d}, J=8.4 \mathrm{~Hz}, 2 \mathrm{H}), 7.72(\mathrm{~d}, J=8.4 \mathrm{~Hz}, 2 \mathrm{H}), 7.60(\mathrm{~d}, J=8.4 \mathrm{~Hz}, 2 \mathrm{H}), 7.28-7.38(\mathrm{~m}, 6 \mathrm{H}), 7.19-7.23(\mathrm{~m}, 2 \mathrm{H})$, $7.12(\mathrm{~d}, J=6.0 \mathrm{~Hz}, 4 \mathrm{H}), 5.40-5.42(\mathrm{~m}, 2 \mathrm{H}), 4.61-4.63(\mathrm{~m}, 2 \mathrm{H})$; IR (KBr) 3050, 1941, 1601, 1548, 1509, 1408 , 999, $784 \mathrm{~cm}^{-1}$; MS m/z 462 (M+, $\left.1.1 \%\right), 280$ (10), 279 (7), 232 (27), 231 (100), 230 (62), 202 (10), 153 (15), 152 (11). HRMS calcd. for $\mathrm{C}_{34} \mathrm{H}_{27} \mathrm{~N}_{2} 463.21742(\mathrm{M}+\mathrm{H})^{+}$, found 463.21465 .

Compound 4b: A pale-yellow oil: ${ }^{1} \mathrm{H}-\mathrm{NMR}\left(400 \mathrm{MHz}, \mathrm{CDCl}_{3}\right) \delta 8.48(\mathrm{~d}, J=5.6 \mathrm{~Hz}, 4 \mathrm{H}), 7.86(\mathrm{~d}$, $J=8.4 \mathrm{~Hz}, 2 \mathrm{H}), 7.82(\mathrm{~d}, J=6.4 \mathrm{~Hz}, 4 \mathrm{H}), 7.65(\mathrm{~d}, J=8.4 \mathrm{~Hz}, 2 \mathrm{H}), 7.58(\mathrm{t}, J=7.2 \mathrm{~Hz}, 2 \mathrm{H}), 7.44(\mathrm{t}, J=7.2 \mathrm{~Hz}$, 2H), 7.22-7.25 (m, 2H), $7.21(\mathrm{~d}, J=6.4 \mathrm{~Hz}, 4 \mathrm{H}), 4.60-4.65(\mathrm{~m}, 2 \mathrm{H}), 4.07-4.12(\mathrm{~m}, 2 \mathrm{H}) ; \mathrm{IR}(\mathrm{KBr}) 3049$, 2915, 1598, 1559, 1507, 1413, 993, 800, $781 \mathrm{~cm}^{-1}$; MS m/z 462 (M+1.9\%), 232 (47), 231 (100), 230 (89), 202 (12). HRMS calcd. for $\mathrm{C}_{34} \mathrm{H}_{27} \mathrm{~N}_{2} 463.21742(\mathrm{M}+\mathrm{H})^{+}$, found 463.21515 .

\subsection{X-ray Crystallography}

Single crystals of dimers were mounted on a CryoLoop (Hampton Research, Aliso Viejo, CA, USA). All measurements were made on a Rigaku RAXIS RAPID II imaging plate area detector (Rigaku, Tokyo, Japan) with graphite monochromated $\mathrm{Cu}-\mathrm{K} \alpha$ radiation at $-150{ }^{\circ} \mathrm{C}$. The structures were solved by the direct method and refined by full-matrix least squares on $F^{2}$ using SHELXL 97 [26]. Crystal Data for $2 \mathrm{a}(M=462.59 \mathrm{~g} / \mathrm{mol})$ : monoclinic, space group $P 2_{1}, a=10.5616(6) \AA, b=9.5453(6) \AA$, $c=13.5147(7) \AA, \beta=110.173(2)^{\circ}, V=1278.89(12) \AA^{3}, Z=4, D_{\text {calc }}=1.201 \mathrm{~g} / \mathrm{cm}^{3}, 14,679$ reflections measured, 4523 unique $\left(R_{\text {int }}=0.0404\right)$. The final $R 1$ was $0.0761(I>2 \sigma(I))$ and $w R 2$ was 0.2912 (all data). CCDC 747473 contains the supplementary crystallographic data for this paper. Crystal Data for $2 \mathbf{b} \cdot 2 \mathrm{HCl} \cdot 2 \mathrm{H}_{2} \mathrm{O}(M=571.54 \mathrm{~g} / \mathrm{mol})$ : monoclinic, space group $C c, a=13.6293(5) \AA, b=17.9154(7) \AA$, $c=12.9243(5) \AA, \beta=110.971(2)^{\circ}, V=2946.8(2) \AA^{3}, Z=4, D_{\text {calc }}=1.288 \mathrm{~g} / \mathrm{cm}^{3}, 16,003$ reflections measured, 4988 unique $\left(R_{\text {int }}=0.0583\right)$. The final $R 1$ was $0.0552(I>2 \sigma(I))$ and $w R 2$ was 0.1779 (all data). CCDC 747474 contains the supplementary crystallographic data for this paper. Crystal Data for $3 \mathbf{b}(M=462.59 \mathrm{~g} / \mathrm{mol})$ : monoclinic, space group $P 2_{1} / c, a=13.4512(6) \AA, b=13.1979(5) \AA$, $c=14.7875(7) \AA, \beta=110.782(2)^{\circ}, V=2454.38(19) \AA^{3}, Z=4, D_{\text {calc }}=1.252 \mathrm{~g} / \mathrm{cm}^{3}, 26,569$ reflections measured, 4443 unique $\left(R_{\text {int }}=0.0451\right)$. The final $R 1$ was $0.0570(I>2 \sigma(I))$ and $w R 2$ was 0.2043 (all data). CCDC 747475 contains the supplementary crystallographic data for this paper. Crystal Data for 4a $(M=462.59 \mathrm{~g} / \mathrm{mol})$ : orthorhombic, space group Pbca, $a=22.5434(4) \AA, b=8.91677(10) \AA$, $c=49.7495(10) \AA, V=10,000.4(3) \AA^{3}, Z=12, D_{\text {calc }}=0.922 \mathrm{~g} / \mathrm{cm}^{3}, 104,123$ reflections measured, 9132 unique $\left(R_{\text {int }}=0.0690\right)$. The final $R 1$ was $0.0648(I>2 \sigma(I))$ and $w R 2$ was 0.2166 (all data). CCDC 747476 contains the supplementary crystallographic data for this paper. These data can be obtained free of charge via http:/ / www.ccdc.cam.ac.uk/conts/retrieving.html (or from the CCDC, 12 Union Road, Cambridge CB2 1EZ, UK; Fax: +44 1223 336033; E-mail: deposit@ccdc.cam.ac.uk).

\section{Conclusions}

$[2+2]$ Photodimerization of naphthylvinylpyridines in the presence of $\mathrm{HCl}$ in $\mathrm{MeOH}$ gave synHT dimers with excellent regio- and stereoselectivities. This synHT preference strongly suggests the formation of preorganized head-to-tail molecular dimers from the intermediate naphthylvinylpyridinium salts through intermolecular cation- $\pi$ interactions. The much higher selectivities compared to that of styrylpyridine reveal the effectiveness of the extended $\pi$-systems on the selectivity of the photodimerization. Another remarkable feature observed under the acidic conditions was that the visible light was also capable of inducing [2+2] photocycloaddition. These results show that $\mathrm{HCl}$ plays essential roles in both the cation- $\pi$ complex formation and the changes in the absorption properties of substrates that enable visible light reactions. As longer conjugate systems 
generally form a stronger cation- $\pi$ complex with a cation, such systems are useful not only in [2 + 2] photocycloaddition, but also in various cation- $\pi$-controlled organic reactions.

Supplementary Materials: Supplementary materials are available online. Figures S1-S7: ${ }^{1} \mathrm{H}-\mathrm{NMR}$ spectra for $\mathbf{2 a}-\mathbf{5} \mathbf{a}$ and $\mathbf{2 b}-\mathbf{4} \mathbf{b}$, Figures S8-S13: MS spectra for $\mathbf{3 a}, \mathbf{4 b}$ and $\mathbf{5 a}$, Figure S14: Plots of 1/[1a] vs t.

Acknowledgments: This work was financially supported by a Grant-in-Aid for Scientific Research (C) (No. 21550097) from the Ministry of Education, Culture, Sports, Science, and Technology (MEXT) of Japan.

Author Contributions: Yuka Nojiri performed the experimental works; Shinji Yamada conceived and designed the project; Shinji Yamada wrote the paper.

Conflicts of Interest: The authors declare no conflict of interest.

\section{References}

1. Horspool, W.M. Synthetic Organic Photochemistry; Plenum Press: New York, NY, USA, 1984; pp. 1-143.

2. Coyle, J.C. Photochemistry in Organic Synthesis; The Royal Society of Chemistry: London, UK, 1986; pp. 163-188.

3. Griesbeck, A.G.; Mattay, J. Synthetic Organic Photochemistry; Marcel Dekker: New York, NY, USA, 2005; pp. 141-160.

4. Poplata, S.; Tröster, A.; Zou, Y.-Q.; Bach, T. Recent Advances in the Synthesis of Cyclobutanes by Olefin [2 + 2] Photocycloaddition Reactions. Chem. Rev. 2016, 116, 9748-9815. [CrossRef] [PubMed]

5. Ramamurthy, V. Organic photochemistry in organized media. Tetrahedron 1986, 42, 5753-5839. [CrossRef]

6. Ramamurthy, V.; Venkatesan, K. Photochemical reactions of organic crystals. Chem. Rev. 1987, 87, 433-481. [CrossRef]

7. Toda, F. Solid State Organic Chemistry: Efficient Reactions, Remarkable Yields, and Stereoselectivity. Acc. Chem. Res. 1995, 28, 480-486. [CrossRef]

8. Gamlin, J.N.; Jones, R.; Leibovich, M.; Patrick, B.; Scheffer, J.R.; Trotter, J. The ionic auxiliary concept in solid state organic photochemistry. Acc. Chem. Res. 1996, 29, 203-209. [CrossRef]

9. Ito, Y. Solid-state photoreactions in two-component crystals. Synthesis 1998, 1-32. [CrossRef]

10. Nagarathinam, M.; Peedikakkal, A.M.P.; Vittal, J.J. Stacking of double bonds for photochemical [2 + 2] cycloaddition reactions in the solid state. Chem. Commun. 2008, 5277-5288. [CrossRef] [PubMed]

11. Georgiev, I.G.; MacGillivray, L.R. Metal-mediated reactivity in the organic solid state: From self-assembledcomplexes to metal-organic frameworks. Chem. Soc. Rev. 2007, 36, 1239-1248. [CrossRef] [PubMed]

12. MacGillivray, L.R.; Papaefstathiou, G.S.; Friščić, T.; Hamilton, T.D.; Bucar, D.-K.; Chu, Q.; Varshney, D.B.; Georgiev, I.G. Supramolecular control of reactivity in the solid state: from templates to ladderanes to metal-organic frameworks. Acc. Chem. Res. 2008, 41, 280-291. [CrossRef] [PubMed]

13. Skiredj, A.; Beniddir, M.A.; Joseph, D.; Leblanc, K.; Bernadat, G.; Evanno, L.; Poupon, E. Spontaneous biomimetic formation of $( \pm)$-dictazole B under irradiation with artificial sunlight. Angew. Chem. Int. Ed. 2014, 53, 6419-6424. [CrossRef] [PubMed]

14. Serrano, E.; Juan, A.; Garca-Montero, A.; Soler, T.; Jimenez-Marquez, F.; Cativiela, C.; Gomez, M.V.; Urriolabeitia, E.P. Stereoselective Synthesis of 1,3-Diaminotruxillic acid derivatives: an advantageous combination of C-H-ortho-Palladation and On-Flow [2+2]-Photocycloaddition in microreactors. Chem. Eur. J. 2016, 22, 144-152. [CrossRef] [PubMed]

15. MacGillivray, L.R. Organic Synthesis in the Solid State via Hydrogen-Bond-Driven Self-Assembly. J. Org. Chem. 2008, 73, 3311-3317. [CrossRef] [PubMed]

16. Ramamurthy, V; Sivaguru, J. Supramolecular photochemistry as a potential synthetic tool: photocycloaddition. Chem. Rev. 2016, 116, 9914-9993. [CrossRef] [PubMed]

17. Ma, J.C.; Dougherty, D.A. The cation- $\pi$ interaction. Chem. Rev. 1997, 97, 1303-1324. [CrossRef] [PubMed]

18. Yamada, S.; Uematsu, N.; Yamashita, K. Role of cation- $\pi$ interactions in the photodimerization of trans-4-styrylpyridines. J. Am. Chem. Soc. 2007, 129, 12100-12101. [CrossRef] [PubMed]

19. Yamada, S.; Nojiri, Y.; Sugawara, M. [2 + 2] Photodimerization of (Z)-4-styrylpyridine through a cation- $\pi$ interaction: Formation of cis-cis-trans dimers. Tetrahedron Lett. 2010, 51, 2533-2535. [CrossRef] 
20. Yamada, S.; Kusafuka, M.; Sugawara, M. [2 + 2] Photodimerization of bispyridylethylenes by a controlled shift of the protonation equilibrium. Tetrahedron Lett. 2013, 54, 3997-4000. [CrossRef]

21. Yamada, S.; Kawamura, C. [4+4] Photodimerization of azaanthracenes in both solution and solid phase controlled by cation- $\pi$ interactions. Org. Lett. 2012, 14, 1572-1575. [CrossRef] [PubMed]

22. Yamada, S.; Tokugawa, Y. Cation- $\pi$ controlled solid-state photodimerization of 4-Azachalcones. J. Am. Chem. Soc. 2009, 131, 2098-2099. [CrossRef] [PubMed]

23. Amunugama, R.; Rodgers, M.T. Cation- $\pi$ interactions with a model for an extended $\pi$ network: Absolute binding energies of alkali metal cation-naphthalene complexes determined by threshold collision-induced dissociation and theoretical studies. Int. J. Mass Spectrom. 2003, 227, 1-20. [CrossRef]

24. Hashimoto, S.; Ikuta, S. A theoretical study on the conformations, energetics, and solvation effects on the cation $-\pi$ interaction between monovalent ions $\mathrm{Li}^{+}, \mathrm{Na}^{+}$, and $\mathrm{K}^{+}$and naphthalene molecules. J. Mol. Struct. 1999, 468, 85-94. [CrossRef]

25. Hewlins, M.J.E.; Salter, R. The photochemical cyclodehydrogenation route to polycyclic azaarenes. Synthesis 2007, 2164-2174. [CrossRef]

26. Sheldrick, G.M. SHELXL-97; Computer Program for Crystal Structure Refinement; University of Göttingen: Göttingen, Germany, 1997.

Sample Availability: Not available.

(C) 2017 by the authors. Licensee MDPI, Basel, Switzerland. This article is an open access article distributed under the terms and conditions of the Creative Commons Attribution (CC BY) license (http://creativecommons.org/licenses/by/4.0/). 